\title{
一般用単相誘導電動機の有効巻数比の簡易測定法
}

\section{正員堀口光敏 (日本工業大学)}

\author{
Simplified Measurement Method of Turn-ratios of Auxiliary Windings in Single Phase Induction Motors \\ for General Purpose. \\ Mitsutoshi Horiguchi, Member (Nippon Institute of Technology)
}

\begin{abstract}
The turn-ratio test is required in single phase induction motor to obtain the data necessary to segregate the losses. In this study, for the single phase induction motors for general purpose that are used widely as single phase induction motors it is discussed that the turn-ratio can be derived from the data obtained in the experiment similar to the locked rotor test for the determination of load characteristics in a polyphase induction motor.
\end{abstract}

キーワード : 単相誘導電動機、主巻線有効巻数、補助巻線有効巻数

\section{1.まえがき}

特性計算に関する研究においては、公表できない設計值 については実測法によってそれを求めなければ、先には進 めない。単相誘導電動機における有効巻数比（=補助巻線有 効巻数/主巻線有効巻数）もその1つであるが、有効巻数比の 実測法についての論文はないようである”。

本稿では、通常の運転速度に達すると、モー夕に内蔵さ れている遠心カスイッチが㗢き、補助巻線が巻線端子から 切り離される一般用笚相誘導電動機 ${ }^{2}$ に対しても、簡便な 測定から有効巻数比は推定できる、について述べている。

\section{2. 算定式の導出}

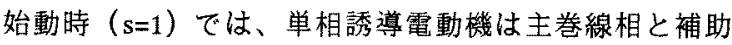

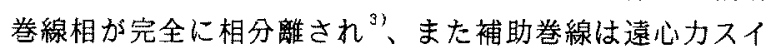
ッチによって補助巻線端子に接続されているから有効巻数 比の測定にはこの始動特性を利用するのが得策である。こ の場合、コンデンサを内蔵するコンデンサ始動電動機など はそのコンデンサの端子間を短絡することによって、電気 回路的には分相始動電動機と同一構造となり得る。

今、図1（a）のように、補助巻線端子間を開放状態に し、主巻線端子間に低電圧の電圧を印加した場合を考える と、主巻線を一次巻線、回転子巻線を二次巻線とする変圧 器と考えることができるから、近似的に次式が成り立つ。

$$
\alpha \mathrm{r}_{2 M}=\frac{\mathrm{W}_{M}}{\mathrm{I}_{M^{2}}}-\mathrm{r}_{1 M} \ldots \ldots \ldots
$$

ここに、 $\alpha$ :表皮効果を考虑する係数 ${ }^{4)} 、$ I :主巻

線電流 $[\mathrm{A}] 、 W_{M}$ :主巻線端子間よりみた消費電力

$[W] 、\ulcorner\mathrm{im}$ :主巻線端子間の直流分の抵抗 $[\Omega]$.

また、同図（b）のように、主巻線端子間は開放状態と し、補助巻線端子間に低電圧の電圧を印加した場合を考え ると、補助巻線を一次巻線、回転子巻線を二次巻線とする

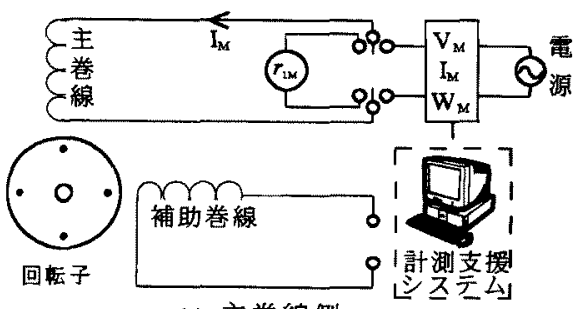

(a) 主巻線側

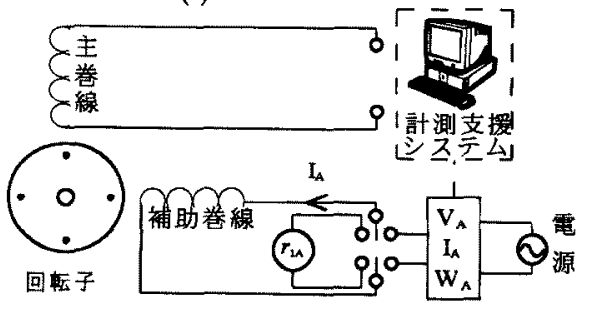

(b) 補助巻線側

図 1 原理図と测定回路

Fig.1. Circuit model and measurement circuits

変压器と考えることができ、近似的に次式が成り立つ。 $\alpha r_{2 A}=\frac{W_{A}}{I_{A}{ }^{2}}-r_{1 A} \ldots . . .$.

ここに、I A : 補助巻線電流 $[\mathrm{A}] 、 W_{\mathrm{A}}$ : 補助巻線端 子間よりみた消費電力 $[W] 、 「 1 A:$ 補助巻線端子間 の直流分の抵抗 $[\Omega]$.

（1）式と（2）式をこのように考えると、（1）式と （2）式におけるI 抗で、「2Mが主巻線側換算值、 $r_{2 A}$ が補助巻線側換算值とな る。従って、「 $\Gamma_{2 A}$ の $\Gamma_{2 M}$ に対する比をとると、この比は補助

$$
a^{2}=\left(\frac{W_{A}}{I_{A}^{2}}-r_{1 A}\right) /\left(\frac{W_{M}}{I_{M}^{2}}-r_{M}\right) \cdot \ldots . .
$$

巻線有効巻数の主巻線有効巻数に対する比の 2 乗で有効巻 数比の 2 乗となり、単相誘導電動機の有効巻数比が電流計、 
有効巻数比の簡易測定法

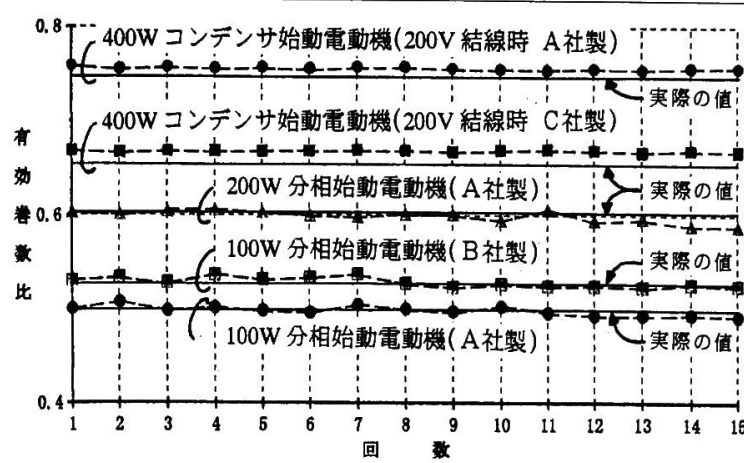

(a) $\boldsymbol{a}<1$ の機械

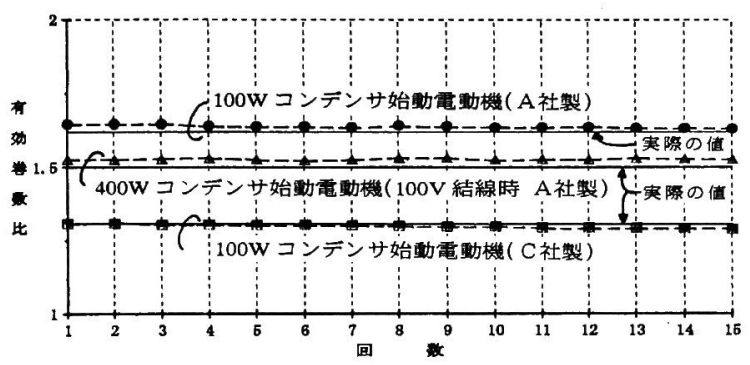

(b) $\quad \boldsymbol{a}>1$ の機械

図 2 実験結果

Fig.2. Experimental results

電力計及びオーム計の各読みから（３）式によって求めら れることになる。

\section{3. 測定方法と結果}

$<3 \cdot 1>$ 測定方法 $^{5)}$ 実用的な測定回路は図 1 で、 GP-IB 付のデジタル AC パワーメータを用いて計測支援シ ステムを採用するとよい。

この方法では、同じような実験を 2 度綝り返すことにな るが、測定中の巻線の温度上昇を抑制できること、使用す る計器が少なくて済むこと及び電源設備容量も小さくて済 むことなどの利点を有する。

$<3 \cdot 2>$ 結果とその検討 測定結果を四 2 に示す。 図 2 の結果は、使用する計器の分解能を考虑して、主巻線 には定格電流の $2 / 3$ 倍位の電流を流すに必要な電圧を印 加、そして、補助巻線には、有効巻数比が 1 より小さい機 械に対しては $\mathrm{V}_{\mathrm{A}}=0.6 \mathrm{~V} \mathrm{M}$ の関係の電圧を、また、有効巻 数比が 1 より大きい機械では $\mathrm{V}_{\mathrm{A}} \fallingdotseq \mathrm{V}_{\mathrm{M}}$ の関係の電圧を、 それそれ印加した場合の諸量における計算結果である。

図 2 に明らかなように、いずれのメーカの製品について も実際の値を $3 \%$ 以内の精度で推定できることがわかる。

なお、供試機の中には、巻線分布係数比（二補助巻線の巻線 分布係数／主巻線の巻線分布係数）が 1.00 の製品もあれば 1.13 の 製品もある。また、銅量比（=補助巻線の銅量／主巻線の銅量） については、 0.58 の製品もあれば、0.14の製品もあった。

しかし、いずれの製品についても測定結果に大差がない ことがわかる。ここに、100W コンデンサ始動電動機（A

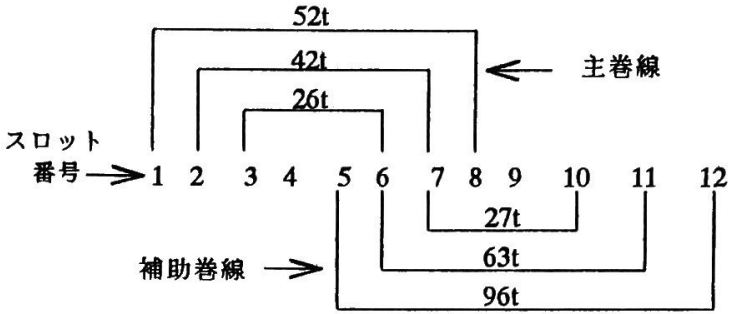

図 3 巻線分布の例

Fig.3. Example of the distribution of windings

社製）の巻線分布図を図 3 に示す。定格電圧は $100 \mathrm{~V}$ 、定 格電流は 3.6/3.0A、定格出力は $100 \mathrm{~W}$ 、極数は 4 極で、固 定子スロット数は 32 である。このモー夕の有効巻数比を 図3より求めると 1.62 となり ${ }^{6)}$ 、測定結果は 1.64 である から測定誤差は $1.2 \%$ となる。

\section{4.むすひ}

製品の有効巻数比を負荷特性算定のための拘束試験と同 じような試験から求める方法について述べた。

本法の特長は、被電動機を回転せずに、而も低電圧で測 定ができることである。従って、一般用単相誘導電動機だ けでなく、さらに大きな容量の単相モータであっても、同 じように、簡易に、そして精度よく有効巻数比を求めるこ とができることになる。なお、本文（3）式については、 不定形を心配する向きもあるが、実用的なモー夕の場合、 そのような状態は考えにくく、本実測法は、有効巻数比の

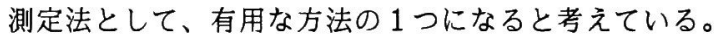

終わりに、有効巻数比の実際の值を提供して頂いた各メ 一力の各位に感謝の意を表わします。

(平成 11 年 1 月 21 日受付, 平成 11 年 3 月 18 日再受付)

\section{文 献}

(1) C.G.VEINOTT:THEORY AND DESIGN OF SMALL INDUCTION MOTORS (McGRAW-HILL) pp.366 367 (1959)

（2）J I S C 4203-1983 一般用単相誘導電動機

（3）例えば、電気学会編：電気学会大学講座電気機械工 学 第 3 巻. 電気学会 p.204 (昭 26)

（4）電気学会編：電気学会大学講座電気機器工学 I（改 訂版) pp.222 223 (1994)

（5）堀口：単相誘導電動機の有効巻線比の簡易測定法 回転機研究会 RM-98-95 pp.25 28 (1998)

（6）石黒・坪島：単相誘導電動機とその応用 オーム社 pp.217 219（昭 34）

堀口光敏 （正員）昭和18年8月6日生まれ。昭和 44 年3

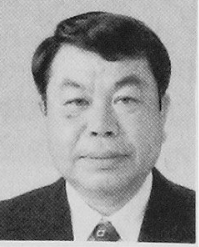
月法政大学工学部電気工学科卒業。同年 4 月日本工業大学工学部電気電子工学科助手 として勤務、昭和 59 年講師現在に至る。主 として、小形誘導電動機の特性算定法と制 御に関する研究に従事。 